\title{
Burnout and Well-Being Levels of Medical Students: a Cross-Sectional Study
}

\section{Níveis de Burnout e Bem-Estar de Estudantes de Medicina: um Estudo Transversal}

\author{
Priscila Gadelha Cazolari ${ }^{I}(\mathbb{D}$ \\ Matheus de Sousa Cavalcante ${ }^{I}(\mathbb{D}$ \\ Marcelo Marcos Piva Demarzo ${ }^{I}(\mathbb{D}$ \\ Frederico Molina Cohrs ${ }^{I}($ iD \\ Adriana Sanudo ${ }^{I}(\mathbb{D})$ \\ Mariana Cabral Schveitzer ${ }^{I}(\mathbb{D})$
}

\section{KEYWORDS}

- Quality of Life.

- Medical Students.

- Mental Health.

- Curriculum.

Introduction: The presence of chronic stress, caused by the activities and demands of the medical course, can lead to what is called 'burnout', a syndrome characterized by three dimensions: emotional exhaustion, dehumanization (or depersonalization) and reduced professional achievement. Considering the increased incidence of burnout syndrome, anxiety and depression symptoms, suicide attempts and suicide rates among medical students, as a consequence of increasing demands for professional and financial success at the expense of physical and mental health, one understands the importance of studying the subject and proposing measures of prevention and control. The aim of this study was to evaluate and describe the levels of burnout and well-being of medical students at a Brazilian public university. Method: The stress and well-being levels of students from the first to the sixth year for the Medical Course at Universidade Federal de São Paulo were evaluated using MBI-SS and WHOQOL-BREF questionnaires, applied online on the REDCAP platform. Results: A total of 302 students completed the questionnaires. Regarding the MBI-SS, students showed a low value in the emotional exhaustion factor and high levels of professional disbelief and effectiveness, indicating a burnout that ranged from low to moderate. It was also observed that female students showed a greater tendency toward emotional exhaustion when compared to male ones, as well as the fact that students from the $1^{\text {st }}$ and $2^{\text {nd }}$ years showed higher values of professional effectiveness when compared with $3^{\text {rd }}$ and $4^{\text {th }}$ years, with no difference between genders. Based on the answers from WHOQUOL-BREF questionnaire, the students thought they had a good quality of life. Discussion: These results reinforce possible factors that might interfere with the students' quality of life: excessive workload, teaching model based on extensive lectures, lack of stimulation, recognition for their efforts. Conclusion: The medical students evaluated in this study have a good quality of life and show low or moderate burnout levels. 


\section{PALAVRAS-CHAVE}

- Qualidade de Vida.

- Estudantes de Medicina.

- Saúde Mental.

- Currículo.

Received on $7 / 14 / 19$

Accepted on 8/10/20

\section{RESUMO}

Introdução: A presença de estresse crônico, causado pelas atividades e exigências do curso de Medicina, pode levar ao que se chama de burnout, uma síndrome caracterizada por três dimensões: exaustão emocional, desumanização (ou despersonalização) e reduzida realização profissional. Diante do aumento da incidência de síndrome de burnout, sintomas de ansiedade e depressão, tentativas de suicídio e suicídio entre estudantes de Medicina, encarado como consequência de exigências cada vez maiores de alcance de sucesso profissional e financeiro em detrimento da saúde física e mental, entende-se a importância de estudar o assunto e propor medidas de prevenção e controle. Este estudo teve como objetivos avaliar e descrever os níveis de burnout e qualidade de vida dos estudantes de Medicina da Universidade Federal de São Paulo. Método: Foram avaliados os níveis de burnout e qualidade de vida dos alunos do primeiro ao sexto ano do curso de Medicina da Unifesp, a partir dos questionários MBI-SS e Whoqol-Bref, on-line, em plataforma REDCap. Resultados: Um total de 302 estudantes responderam aos questionários completos. Em relação ao MBI-SS, os estudantes apresentaram baixo valor no fator exaustão emocional e altos valores na descrença e eficácia profissional, indicando um burnout entre baixo e moderado. Observou-se também que estudantes do gênero feminino apresentaram maior tendência à exaustão emocional em comparação ao gênero masculino, bem como estudantes do primeiro e segundo anos apresentaram maiores valores de eficácia profissional quando comparados com os do terceiro $e$ quarto anos, sem diferença entre os gêneros. A partir das respostas do Whoqol-Bref, os estudantes consideraram ter boa qualidade de vida. Esses resultados indicam possíveis fatores que podem interferir na qualidade de vida dos estudantes: a carga horária excessiva de atividades, modelo de ensino baseado em aulas expositivas extensas, ausência de estímulo e reconhecimento pelos seus esforços. Conclusão: Os estudantes de Medicina avaliados neste estudo têm boa qualidade de vida e níveis baixos ou moderados de burnout, atentando-se para as diferenças entre anos de curso e características sociodemográficas.

\section{INTRODUCTION}

The medical course is a costly and difficult one, from the premed admission, going through a competitive selection process until its completion. After they enter medical school, it is very common for medical students to also experience a great deal of stress in the midst of a huge range of information and demands, in addition to competitiveness, contact with patients with severe diseases and death, leisure deprivation, etc. Studies have shown that the stress that medical students are submitted to can increase during the medical course ${ }^{1,2}$.

The presence of chronic stress, caused by the activities and demands of the course, can lead to 'burnout', a syndrome characterized by three dimensions: emotional exhaustion, dehumanization (or depersonalization) and reduced professional achievement. Emotional exhaustion is characterized by mental and physical exhaustion and a feeling of incapacity, which can lead to symptoms of anxiety and depression. This condition has as consequence (and also as cause) the dehumanization, which would be a state where the individual becomes indifferent, impersonal, ironic and cynical towards other people, as a form of social distancing and in an attempt to minimize exhaustion. Finally, the activities performed by the individual lose their meaning and they have a feeling of failure and dissatisfaction ${ }^{2,3}$.

Burnout can have implications that range from the personal level, which can have drug abuse and suicide as the most severe consequences, to the professional and collective scenarios, which can result in risk to their own patients. Among the main physical consequences of burnout are excessive tiredness, sleep disorders, muscle pain, headache, gastrointestinal disorders, eating disorders and immunodeficiencies. The cognitive signs and symptoms may include difficulty concentrating, decreased memory and slow thinking; the emotional ones comprise irritation, anxiety, depression, feeling discouraged and aggression; and the behavioral ones include inhibition, negligence, loss of initiative, tendency to isolation, lack of interest in work and/or leisure and lack of flexibility ${ }^{4-7}$.

National and international studies show that the rates of stress, anxiety, depression and burnout are higher among medical students when compared to that of the general population. A longitudinal study carried out with medical students at Universidade Estadual de Maringá, showed an increase in the dehumanization component and a decrease in professional achievements over the years. This same study showed a peak emotional exhaustion in the fourth year, with a subsequent decrease ${ }^{1}$. Another study carried out in Uruguay found a $14.7 \%$ prevalence of burnout in students attending internship (fifth and sixth-year students); however, it highlights the importance of analyzing each component separately. Using the Maslach Burnout Inventory - Human Services Survey (MBI-HSS), the study pointed out that $28.3 \%$ of interns had emotional exhaustion and $30.6 \%$ showed depersonalization ${ }^{8}$.

According to the WHOQOL (Word Health Organization Quality of Life) questionnaire, quality of life is the "individual's perception of their position in life in the context of the culture and system of values in which they live and in relation to their goals, expectations, standards and concerns" ${ }^{\prime 9,10}$. Studies that evaluate the quality of life in medical students have different results, but all indicate factors that should receive more attention according to the observed population. Among the medical students at Faculdade de Ciências Médicas de Sorocaba, $86 \%$ of the respondents in the first year and $88 \%$ in the sixth year considered their

REVISTA BRASILEIRA DE EDUCAÇÃO MÉDICA

2 44 (4) : e125; 2020 
quality of life to be "good" or "very good". Among these groups, there was a difference only regarding the social domain, which could be explained by the adaptation period experienced by students in the first year. However, one-third of the students had low scores in at least three of the assessed domains and one-quarter were not satisfied with their health ${ }^{11}$.

Therefore, considering the increased incidence of burnout syndrome, symptoms of anxiety and depression, suicide attempts and suicide rates among medical students, seen as a result of increasing demands for professional and financial success to the detriment of physical and mental health, one understands the importance of studying the subject and proposing prevention and control measures.

In this context, the aim of the present study was to assess and describe the levels of burnout and well-being of medical students at UNIFESP.

\section{METHOD}

The is a quantitative, cross-sectional and descriptive study. The levels of stress and quality of life of students from the first to the sixth year of the medical course at Universidade Federal de São Paulo - UNIFESP were evaluated. The inclusion criterion comprised being duly enrolled in the medical course at Escola Paulista de Medicina - UNIFESP.

Data collection was carried out using online self-reported questionnaires, through the REDCap platform. The Malasch Burnout Inventory - Students Survey (MBI-SS) and WHOQOL-BREF questionnaires were applied, in addition to a sociodemographic questionnaire consisting of the following data: gender, age, marital status, type of school (public, private or mixed), housing (friends, family, alone, others), medical school financing (scholarship, family, student's own funds).

The MBI-SS was designed to assess burnout syndrome in students ${ }^{12}$ and consists of 15 items distributed among the following dimensions: exhaustion (5 questions), disbelief (4 questions) and professional effectiveness (6 questions). In its original version, the MBI-SS makes it possible to calculate, by means of the sum of the respective items, the scores of exhaustion, disbelief and professional effectiveness. An individual is diagnosed with burnout syndrome, in relation to his group, if they are simultaneously above the $66^{\text {th }}$ percentile of the Exhaustion and Disbelief scores and below the $33^{\text {rd }}$ percentile of the achievement scores ${ }^{12,13}$. Each domain is classified as low, medium or high, with their respective cutoff points. Namely: emotional exhaustion (low when below 19, medium between 19 and 26 and high when greater than or equal to 27); disbelief (low when below 6, medium between 6 and 9 and high when greater than or equal to 10 points) and professional effectiveness (low when below or equal to 40 , medium between 34 and 39 and high when lower than or equal to 33).

The WHOQOL-BREF contains 26 questions, 2 of which are more general, about quality of life and satisfaction with health, and the remaining 24 are divided into 4 domains: physical (seven questions about pain and discomfort, energy and fatigue, sleep and rest, mobility, activities of daily living, use of medication and ability to work), psychological (six questions about positive and negative feelings, thinking and learning, memory and concentration, body image and spirituality), social relations (three questions about personal relationships, social support and sexual activity) and environment (eight questions about physical safety and protection, home environment, financial resources, availability and quality of health and social care, opportunities to acquire new information and skills, leisure activities, physical environment and transportation). The final score can range from 0 to 100, with 100 being the most favorable to quality of life $\mathrm{e}^{14,15}$.

A total of 720 medical students (120 students per year of the medical course - total number of vacancies from the first to the sixth year) were invited to answer the questionnaires through message/social network groups. The questionnaires were made available from August to October 2017 through an online link and posted on social networks and message groups of each year of the course. The study was submitted to the Research Ethics Committee and to the Graduation Council of Universidade Federal de São Paulo (approval number 2,351,354). All participants signed the Free and Informed Consent Form, which presented the information about the research and also about an existing support resource at the University so that they could seek out if they felt they needed it.

\section{Statistical analysis}

The demographic data were described using numbers and percentages for categorical variables. Boxplot-type graphs were constructed for the numerical variables aiming to assess the distribution of the analyzed variables. The assumption of normality of the quantitative variables was carried out using the Shapiro-Wilk test. As the data showed a normal distribution, it was decided to summarize the information as mean \pm standard deviation.

The mean score of each dimension of the MBI-SS and WHOQOLBREF instruments was compared between the years of the course adjusted for gender through an analysis of variance with two factors, using the two-way ANOVA test, whereas the post hoc test was carried out using Bonferroni's multiple comparison test.

The correlation between the WHOQOL-BREF domains and the MBISS dimensions was assessed by calculating Pearson's correlation coefficient.

A significance level of $5 \%$ was adopted for all statistical analyses, that is, results with a $p$ value $<5 \%(p<0.05)$ were considered statistically significant. All analyses were performed using STATA/SE 15.1 for Windows.

\section{RESULTS}

Of the 720 students who were invited to answer the questionnaires, a total of 302 complete responses were obtained for the MBI-SS and WHOQOL-BREF $(n=302)$. The sociodemographic data of the included students is shown in Table 1 .

According to Table 1, it can be observed that the female gender was the most prevalent (55\%), and the students' age ranged from 18 to 35 years. These students were mostly single (96\%), had studied at a private school (67.9\%), lived with their family and had their tuition paid by the family.

Regarding the cutoff values for the MBI-SS dimensions, regarding emotional exhaustion, of the 302 evaluated students, it was observed that most of them (64.9\%) had emotional exhaustion that was considered low $(<19)$. As for the disbelief dimension, it was observed that $86 \%$ of them had high disbelief. Regarding professional effectiveness, all 302 students obtained high values, which is considered good professional effectiveness. These results are shown in Figure 1.

Table 2 shows the means of the MBI-SS questionnaire for medical students according to gender and year of the medical course.

Regarding emotional exhaustion, all assessed years $\left(1^{\text {st }}\right.$ and $2^{\text {nd }}, 3^{\text {rd }}$ and $4^{\text {th }}, 5^{\text {th }}$ and $6^{\text {th }}$ ) had low values for exhaustion $($ mean $<19)$ and there was no statistically significant difference $(p>0.05)$ between the assessed years.

REVISTA BRASILEIRA DE EDUCAÇÃO MÉDICA

3 44 (4) : e125; 2020 


\begin{tabular}{|c|c|}
\hline \multirow{2}{*}{\multicolumn{2}{|c|}{$\begin{array}{c}\text { Table } 1 \\
\text { Description of the } 302 \text { students participating in the study. São } \\
\text { Paulo, } 2017 .\end{array}$}} \\
\hline & \\
\hline & No $(\%)$ \\
\hline \multicolumn{2}{|l|}{ Gender $^{\text {a }}$} \\
\hline Female & $165(55.0 \%)$ \\
\hline Male & $135(65.0 \%)$ \\
\hline \multicolumn{2}{|l|}{ Age, years } \\
\hline Mean \pm standard deviation & $23.2 \pm 3.0$ \\
\hline Minimum - Maximum & $18-35$ \\
\hline \multicolumn{2}{|l|}{ Year of the Course } \\
\hline $1^{\mathrm{s}} \mathrm{t}$ and $2^{\text {nd }}$ year & $113(37.4 \%)$ \\
\hline $3^{\text {rd }}$ and $4^{\text {th }}$ year & $85(28.2 \%)$ \\
\hline $5^{\text {th }}$ and $6^{\text {th }}$ year & $104(34.4 \%)$ \\
\hline \multicolumn{2}{|l|}{ Marital status ${ }^{\text {a }}$} \\
\hline Single & $288(96.0 \%)$ \\
\hline Common-law marriage & $12(4.0 \%)$ \\
\hline \multicolumn{2}{|l|}{ School type } \\
\hline Public & $61(20.2 \%)$ \\
\hline Mixed & $36(11.9 \%)$ \\
\hline Private & $205(67.9 \%)$ \\
\hline \multicolumn{2}{|l|}{ Housing } \\
\hline Family & $158(52.3 \%)$ \\
\hline Friends & $88(29.1 \%)$ \\
\hline Alone & $48(15.9 \%)$ \\
\hline Others & $8(2.7 \%)$ \\
\hline \multicolumn{2}{|l|}{ School Funding } \\
\hline Family & $254(84.1 \%)$ \\
\hline Scholarship & $9(3.0 \%)$ \\
\hline Student's own resources & $10(3.3 \%)$ \\
\hline Family + Scholarship & $18(6.0 \%)$ \\
\hline Family + Student's own resources & $8(2.6 \%)$ \\
\hline Family + Scholarship + Student's own resources & $(1.0 \%)$ \\
\hline
\end{tabular}

${ }^{\text {aT }}$ Two questionnaires lacked the information Source: research data.

Regarding disbelief, it was observed that all the assessed years had high values for disbelief (mean $\geq 10$ ) without any significant difference between the years of the course.

For professional effectiveness, it was observed that all years had low mean values, which inversely indicates good professional effectiveness. However, there was a statistically significant difference; $1^{\text {st }}$ and $2^{\text {nd }}$ years had a higher mean professional effectiveness value than those of the $3^{\text {rd }}$ and $4^{\text {th }}$ years $(\mathrm{p}=0.009)$.

Regarding gender, the data suggest a slight tendency towards greater exhaustion among female students in the $3^{\text {rd }}$ and $4^{\text {th }}$ years. There was no difference in relation to disbelief and in relation to

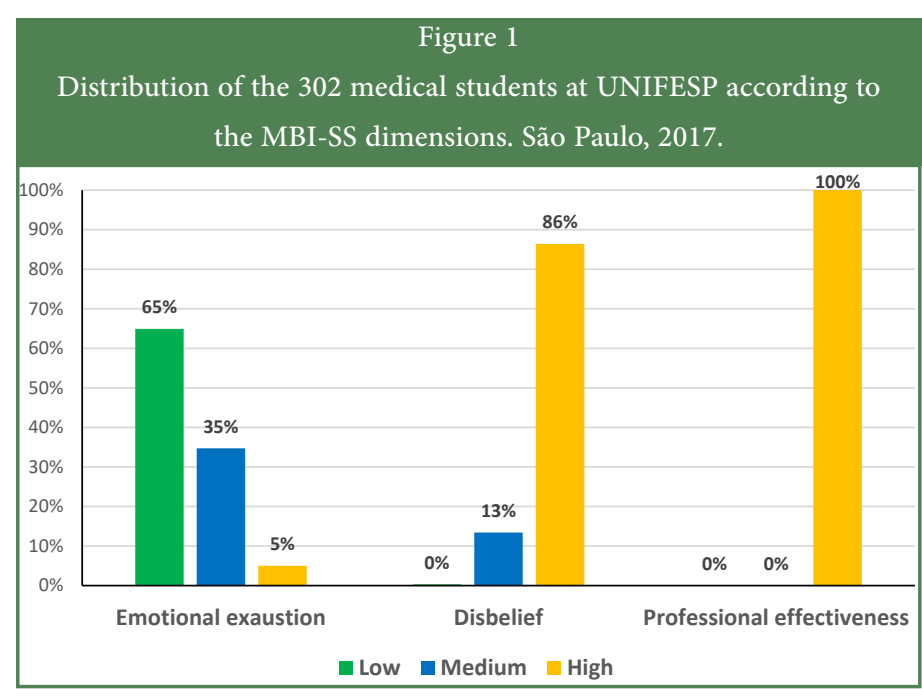

Source: research data.

\section{Table 2}

Mean \pm standard deviation of the values of emotional exhaustion,

disbelief and professional effectiveness according to the year of the

medical course and gender at the MBI-SS questionnaire of medical students at Unifesp, São Paulo, 2017.

\begin{tabular}{|c|c|c|c|c|c|}
\hline \multirow{2}{*}{ MBI-SS } & \multicolumn{5}{|c|}{ Years of the Medical Course } \\
\hline & & $1^{\text {st }}$ and $2^{\text {nd }}$ & $3^{\text {rd }}$ and $4^{\text {th }}$ & $5^{\text {th }}$ and $6^{\text {th }}$ & p-value \\
\hline \multirow{3}{*}{$\begin{array}{l}\text { Emotional } \\
\text { Exhaustion }\end{array}$} & Female & $\begin{array}{c}17.8 \pm 3.5 \\
(\mathrm{n}=58)\end{array}$ & $\begin{array}{c}17.3 \pm 3.4 \\
(\mathrm{n}=45)\end{array}$ & $\begin{array}{c}17.1 \pm 3.4 \\
(n=62)\end{array}$ & 0.538 \\
\hline & Male & $\begin{array}{c}17.1 \pm 3.9 \\
(\mathrm{n}=55)\end{array}$ & $\begin{array}{c}15.6 \pm 3.1 \\
(\mathrm{n}=39)\end{array}$ & $\begin{array}{c}15.7 \pm 3.7 \\
(\mathrm{n}=41)\end{array}$ & \multirow[t]{2}{*}{0.054} \\
\hline & p-value & 0.330 & 0.003 & 0.004 & \\
\hline \multirow{3}{*}{ Disbelief } & Female & $\begin{array}{c}13.3 \pm 4.1 \\
(\mathrm{n}=58)\end{array}$ & $\begin{array}{c}14.5 \pm 4.3 \\
(\mathrm{n}=45)\end{array}$ & $\begin{array}{c}15.6 \pm 4.3 \\
(\mathrm{n}=62)\end{array}$ & 0.009 \\
\hline & Male & $\begin{array}{c}14.1 \pm 3.4 \\
(\mathrm{n}=55)\end{array}$ & $\begin{array}{c}13.2 \pm 3.8 \\
(\mathrm{n}=39)\end{array}$ & $\begin{array}{c}13.8 \pm 3.8 \\
(\mathrm{n}=41)\end{array}$ & \multirow[t]{2}{*}{0.528} \\
\hline & p-value & 0.285 & 0.865 & 0.591 & \\
\hline \multirow{3}{*}{$\begin{array}{l}\text { Professional } \\
\text { Effectiveness }\end{array}$} & Female & $\begin{array}{c}19.7 \pm 4.1 \\
(\mathrm{n}=58)\end{array}$ & $\begin{array}{c}18.6 \pm 4.3 \\
(\mathrm{n}=45)\end{array}$ & $\begin{array}{c}18.7 \pm 4.3 \\
(\mathrm{n}=62)\end{array}$ & 0.284 \\
\hline & Male & $\begin{array}{c}19.3 \pm 3.4 \\
(\mathrm{n}=55)\end{array}$ & $\begin{array}{c}16.6 \pm 3.8 \\
(\mathrm{n}=39)\end{array}$ & $\begin{array}{c}17.7 \pm 3.8 \\
(\mathrm{n}=41)\end{array}$ & \multirow[t]{2}{*}{0.006} \\
\hline & p-value & 0.551 & $<0.001$ & 0.013 & \\
\hline
\end{tabular}

Source: research data

professional effectiveness; the data indicate higher values among female students.

Regarding the students' quality of life based on the WHOQOL-BREF responses, the data were analyzed from each domain and organized in Figure 2. The means of each score were as follows: Environmental (70.4), Social Relations (68.7), Psychological (65.2) and Physical (67.9) domains, considered values between fair and good, with no statistical difference between the assessed domains, both between genders and between the years of medical course (Table 3 ). 


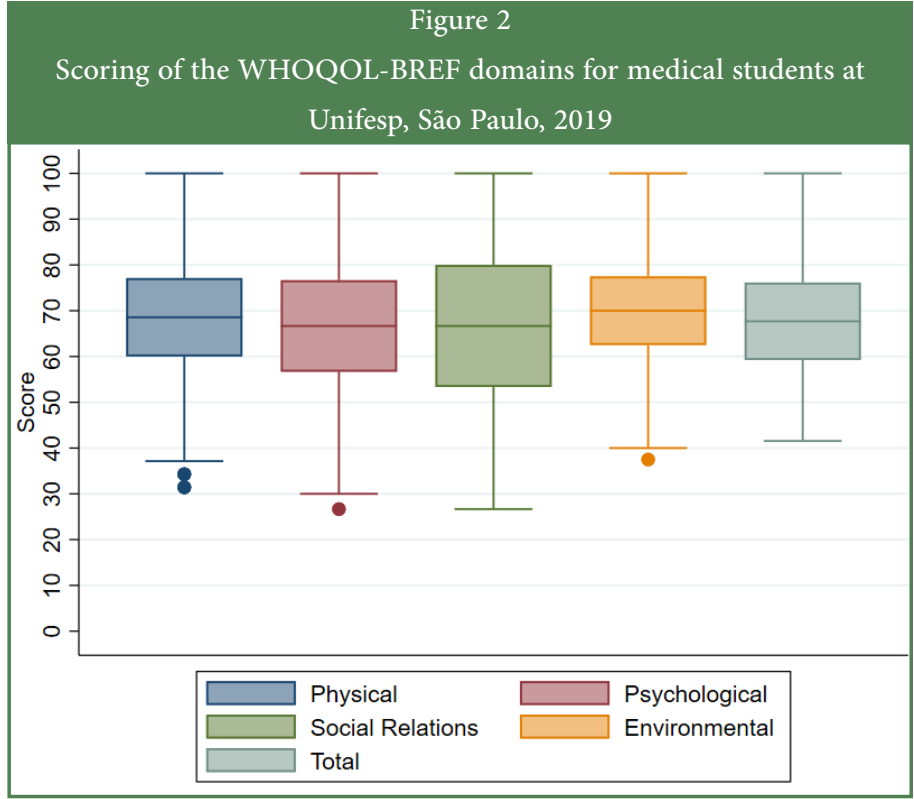

Source: research data.

Table 3

Mean \pm standard deviation of the WHOQOL domains of medical

students at Unifesp according to the year of the course and gender, São Paulo, 2019

WHOQOL

Years of the medical course

\begin{tabular}{|c|c|c|c|c|c|}
\hline & & $1^{\text {st }}$ and $2^{\text {nd }}$ & $3^{\text {rd }}$ and $4^{\text {th }}$ & $5^{\text {th }}$ and $6^{\text {th }}$ & p-value \\
\hline \multirow{3}{*}{$\begin{array}{l}\text { Physical } \\
\text { Domain }\end{array}$} & Female & $\begin{array}{c}14.1 \pm 2.5 \\
(\mathrm{n}=93)\end{array}$ & $\begin{array}{c}12.9 \pm 2.6 \\
(\mathrm{n}=65)\end{array}$ & $\begin{array}{c}12.5 \pm 2.5 \\
(\mathrm{n}=89)\end{array}$ & 0.004 \\
\hline & Male & $\begin{array}{c}14.6 \pm 2.3 \\
(\mathrm{n}=55)\end{array}$ & $\begin{array}{c}14.2 \pm 2.9 \\
(\mathrm{n}=66)\end{array}$ & $\begin{array}{c}14.0 \pm 2.7 \\
(\mathrm{n}=53)\end{array}$ & \multirow[t]{2}{*}{0.596} \\
\hline & $\mathrm{p}$-value & 0.729 & 0.751 & 0.540 & \\
\hline \multirow{3}{*}{$\begin{array}{l}\text { Psychological } \\
\text { Domain }\end{array}$} & Female & $\begin{array}{c}13.4 \pm 2.6 \\
(n=93)\end{array}$ & $\begin{array}{c}12.3 \pm 2.8 \\
(\mathrm{n}=65)\end{array}$ & $\begin{array}{c}12.0 \pm 2.9 \\
(n=89)\end{array}$ & 0.023 \\
\hline & Male & $\begin{array}{c}13.5 \pm 2.5 \\
(\mathrm{n}=55)\end{array}$ & $\begin{array}{c}14.0 \pm 3.3 \\
(\mathrm{n}=66)\end{array}$ & $\begin{array}{c}13.4 \pm 3.1 \\
(\mathrm{n}=53)\end{array}$ & \multirow[t]{2}{*}{0.448} \\
\hline & $\mathrm{p}$-value & 0.969 & 0.251 & 0.983 & \\
\hline \multirow{3}{*}{$\begin{array}{c}\text { Social Relations } \\
\text { Domain }\end{array}$} & Female & $\begin{array}{c}13.8 \pm 3.1 \\
(\mathrm{n}=93)\end{array}$ & $\begin{array}{c}13.2 \pm 3.2 \\
(\mathrm{n}=65)\end{array}$ & $\begin{array}{c}13.5 \pm 3.4 \\
(\mathrm{n}=89)\end{array}$ & 0.183 \\
\hline & Male & $\begin{array}{c}13.7 \pm 2.9 \\
(\mathrm{n}=55)\end{array}$ & $\begin{array}{c}14.5 \pm 3.7 \\
(\mathrm{n}=66)\end{array}$ & $\begin{array}{c}13.8 \pm 3.4 \\
(\mathrm{n}=53)\end{array}$ & \multirow[t]{2}{*}{0.209} \\
\hline & $\mathrm{p}$-value & 0.885 & 0.118 & 0.948 & \\
\hline \multirow{3}{*}{$\begin{array}{c}\text { Environmental } \\
\text { Domain }\end{array}$} & Female & $\begin{array}{c}14.6 \pm 2.4 \\
(n=93)\end{array}$ & $\begin{array}{c}13.6 \pm 2.4 \\
(\mathrm{n}=65)\end{array}$ & $\begin{array}{c}13.3 \pm 2.7 \\
(\mathrm{n}=89)\end{array}$ & 0.001 \\
\hline & Male & $\begin{array}{c}14.3 \pm 2.1 \\
(\mathrm{n}=55)\end{array}$ & $\begin{array}{c}15.1 \pm 2.8 \\
(\mathrm{n}=66)\end{array}$ & $\begin{array}{c}14.3 \pm 3.0 \\
(\mathrm{n}=53)\end{array}$ & \multirow[t]{2}{*}{0.241} \\
\hline & $\mathrm{p}$-value & 0.395 & 0.463 & 0.379 & \\
\hline \multirow{3}{*}{ Total } & Female & $\begin{array}{c}14.1 \pm 2.1 \\
(\mathrm{n}=93)\end{array}$ & $\begin{array}{c}13.0 \pm 2.2 \\
(\mathrm{n}=65)\end{array}$ & $\begin{array}{c}12.7 \pm 2.2 \\
(\mathrm{n}=89)\end{array}$ & 0.002 \\
\hline & Male & $\begin{array}{c}14.2 \pm 1.8 \\
(\mathrm{n}=55)\end{array}$ & $\begin{array}{c}14.5 \pm 2.7 \\
(\mathrm{n}=66)\end{array}$ & $\begin{array}{c}14.0 \pm 2.5 \\
(\mathrm{n}=53)\end{array}$ & \multirow[t]{2}{*}{0.344} \\
\hline & $\mathrm{p}$-value & 0.859 & 0.304 & 0.646 & \\
\hline
\end{tabular}

When correlating the data, a negative correlation was observed between all domains of the WHOQOL-BREF and the MBI dimensions. That is, it was observed that while there is an increase in the physical, psychological, social relations and environmental domains, characterizing good quality of life, there is a decrease in the dimensions of emotional exhaustion, disbelief and little professional effectiveness. The opposite is also true. That is, decreases in the quality of life domains are related to the increase in MBI burnout dimensions. (Table 4)

\section{DISCUSSION}

A high level of burnout is related to the concomitant presence of high scores related to the factors of exhaustion and disbelief and low scores in the professional effectiveness dimension, whereas a moderate level refers to the presence of mean scores on the three subscales, and a low level is related to low scores related to the exhaustion and disbelief factors and high scores in the professional effectiveness factor. In the present study, the students showed low values in the emotional exhaustion factor and high values in disbelief and professional effectiveness, indicating a burnout ranging from low and moderate $\mathrm{e}^{12,13}$.

In the present study, a statistical difference was found only in the professional effectiveness dimension in the comparison between $1^{\text {st }}$ and $2^{\text {nd }}$ versus $3^{\text {rd }}$ and $4^{\text {th }}$ years. These results are noteworthy, as they show that the students of the first years are less exposed to the stressful burden and other factors when compared with the students from more advanced years, in addition to the loss of the career idealization that occurs as the students face the reality of practical medicine, explaining the differences between professional achievement ${ }^{16}$. We highlight the complexity and multiplicity of functions and tasks that increase as the years of the medical course elapse, in addition to the pressure to pass exams and/or educational evaluations and selection processes for medical residency, which begin to emerge and become common in the routine of older students, especially among those in the fifth and sixth years ${ }^{16}$. Tamayo ${ }^{17}$ also observed higher levels of burnout in the last two years, which correspond to the internship period.

Another problem that is very present and associated with burnout in medical students are sleep disorders ${ }^{18}$. A study carried out at a medical school in Recife ${ }^{19}$ showed that significant percentages of medical students reported poor sleep quality and a smaller but important percentage

\begin{tabular}{|cccc|}
\hline \multicolumn{4}{c}{ Table 4} \\
Correlation* & $\begin{array}{c}\text { Detween WHOQOL-BREF Domains and MBI } \\
\text { Dimensions }\end{array}$ \\
\hline $\begin{array}{c}\text { WHOQOL- } \\
\text { BREF Domains }\end{array}$ & $\begin{array}{c}\text { MBI - Emotional } \\
\text { Exhaustion }\end{array}$ & $\begin{array}{c}\text { MBI - } \\
\text { Disbelief }\end{array}$ & $\begin{array}{c}\text { MBI- Professional } \\
\text { Effectiveness }\end{array}$ \\
\hline Physical & -0.439 & -0.565 & -0.313 \\
\hline Psychological & -0.383 & -0.537 & -0.299 \\
\hline Social relations & -0.285 & -0.267 & -0.247 \\
\hline Environmental & -0.249 & -0.248 & -0.148 \\
\hline TOTAL & -0.424 & -0.513 & -0.309 \\
\hline
\end{tabular}

*Pearson's correlation

Source: research data.

Source: research data. 
reported the presence of a possible sleep disorder. Moreover, the study also pointed out that the scores related to stress were above the cutoff considered for a high level of stress, in addition to quality of life considered regular and screening for the presence of psychopathological disorders with a high percentage of suspicion, predominantly in the female gender. The importance of researching burnout and sleep disorders is because together these two problems can lead to consequences such as low academic performance, abuse of legal and/or illegal drugs, anxiety, depression, suicidal ideation and suicide ${ }^{20,21}$. All of these factors, which may arise from conditions imposed during undergraduate school, affect the quality of life of the students.

Our study showed a greater tendency for women to have emotional exhaustion in the $3^{\text {rd }}$ and $4^{\text {th }}$ years when compared to men. Other studies also depict an important gender focus and the difference between men and women in terms of burnout levels and quality of life in general, which show that female medical students have lower mental health scores when compared to male medical students ${ }^{22}$. What has been explained about these results and gender-based differences are studies that correlate findings of a worse mental health score and emotional exhaustion with the high prevalence of psychiatric disorders, such as anxiety and depression in female students, which is more prevalent when compared with male students and that would reflect the low values found when assessing burnout and other components that encompass mental health ${ }^{23}$.

Another interesting point analyzed in the literature is the academic learning personality showing possible gender differences, which would reflect the different values found for men and women, opening space for future research regarding teaching methodologies that consider profiles and other sociodemographic characteristics before being implemented ${ }^{23}$. Moreover, findings in the literature point to gender stereotypes and disparities that are strongly present not only in medical courses, but in society as a whole and that are related to higher rates of burnout and worse mental health scores in general ${ }^{23-25}$.

Based on the responses of the WHOQOL-BREF, students considered they had a good quality of life, a result similar to that found in the municipality of Sorocaba by Ramos-Dias et $\mathrm{al}^{11}$; however, they feel they have disadvantages regarding the performance of activities of daily living, in their work capacity and in the quality of their sleep. This study did not include an analysis to compare the quality of life in each year of the medical course, and there is no consensus in the literature on how the quality of life changes with the course's evolution. Chazan et $\mathrm{l}^{26}$ found that the students' quality of life worsens during undergraduate school, and Cavalcante et $\mathrm{al}^{27}$ compared data from Unifesp's first and sixth year students and found no statistical difference in 2017; however, in 2018, they found lower scores in the first year-students when compared to the sixth-year ones.

The analysis of the domains contained in the WHOQOL-BREF (physical, psychological, social relations and environmental domains) demonstrated that there is no statistical difference between each of them, with a higher score in the environmental domain, followed by that of social relations, whereas the psychological has the lowest score. The values for each domain were lower than those found by Ramos-Dias et $\mathrm{al}^{11}$ and Chazan et $\mathrm{al}^{26}$, in addition to disagreeing with the values of each domain. In both studies, the domains that had the highest scores were the physical and social relations domains.

In the municipality of Ouro Preto, using the focal group technique and the WHOQOL-BREF questionnaire, it was concluded that the main factor that collaborates to worsen the quality of life of the students are extensive curricular and extracurricular workloads, which make it impossible to practice activities of leisure, rest, healthcare, adequate food, among other components that contribute to a good quality of life ${ }^{28}$. Another study carried out in Rio de Janeiro also concluded that there is a decrease in the quality of life of students throughout undergraduate $\operatorname{school}^{26}$. Likewise, a study carried out in Malaysia ${ }^{29}$ showed that psychopathological conditions, such as anxiety and depression, were associated with a worse QoL. Medical students with symptoms of depression had scores associated with lower physical, psychological and environmental domains, while those with anxiety symptoms had lower scores in the psychological, social and environmental domains.

Furthermore, this study found a negative correlation between burnout and quality of life, that is, high rates of burnout associated with low rates of quality of life, with the reciprocal condition also being true, which is in line with the literature that analyzed several factors that influence burnout and quality of life. Some studies analyze and show the association between the development of burnout and symptoms of anxiety and depression in medical students. Two of them showed a positive association between a healthy lifestyle, physical activity practice and a balanced diet, and lower levels of burnout in the students ${ }^{30,31}$. Another study, carried out in Mexico, states that there is an important association between a resistant personality type and burnout. The study suggests that individuals with this type of personality have a better capacity to perceive and deal with stressful situations, which would be a protective factor for their mental health and, consequently, against the occurrence of burnout syndrome ${ }^{32}$. In contrast, a North American narrative review states that study and working conditions, much more than individual characteristics, are the major determinants of the medical student's well-being and cause of burnout $^{2}$. Moreover, a study carried out in South Africa showed that high burnout rates are associated with medium and low values of quality of life scores assessed by the WHOQOL-BREF, mainly in the psychological domain $^{33}$, which also corroborates the findings of this research.

Regarding the results found in this study, the convenience sample and the inability to generalize the obtained results can be mentioned as limitations of the study.

Finally, given the relevance of the subject, the literature indicates different strategies that can help promote health and quality of life among medical students, such as carrying out conversation circles about compassion $^{34}$ and mindfulness courses ${ }^{35}$, aiming to create a critical selfassessment of students and facilitate access to aid measures, with an institutional view aiming to change paradigms, bringing students closer to mechanisms that contribute to improving the addressed aspects.

\section{CONCLUSION}

The obtained results allow us to conclude that the medical students assessed in this study have a good quality of life and low to moderate levels of burnout, with a negative correlation between the findings. There is a significant difference in relation to gender and emotional exhaustion, with women showing worse results than men, as well as students of the first years showing higher rates of professional achievement when compared to those attending the more advanced years. In this sense, it is very important to disclose these results to the University's employees 
and to create institutional mechanisms to promote the mental health of the institution's medical students, paying attention to the influence of sociodemographic variables and specific characteristics.

\section{ACKNOWLEDGMENT}

This work received funding through Bolsa de Iniciação à Gestão (BIG) from the Pró-Reitoria de Assuntos Estudantis (PRAE of Universidade Federal de São Paulo - Unifesp) granted to the first author.

\section{REFERENCES}

1. Benevides-Pereira AM, Gonçalves MB. Transtornos emocionais e a formação em Medicina: um estudo longitudinal. Rev Bras Educ Med. 2009;33(1):10-23. doi: 10.1590/S0100-55022009000100003.

2. Dyrbye L, Shanafelt T. A narrative review on burnout experienced by medical students and residents. Med Educ. 2016;50(1):132-49. doi: 10.1111/medu.12927.

3. Goni M, Urgoiti, M, Durante E. Correlación entre clima educativo y síndrome de burnout em practicantes internos de la carrera de doctor em medicina de Uruguay. Rev Méd Urug. 2015;31(4):27281 [access in $4 \mathrm{dez}$ 2019]. Available from: http://www.scielo.edu.uy/ scielo.php?script=sci_arttext\&pid=S1688-03902015000400007\&lng= es\&nrm=iso.

4. Almeida GC, Souza HR, Almeida PC, Almeida BC, Almeida GH. The prevalence of burnout syndrome in medical students. Arch Clin Psychiatry. 2016;43(1):6-10. doi:10.1590/0101-60830000000072.

5. Tabalipa FO, Souza MF, Pfützenreuter G, Lima VC, Traebert E. Prevalence of anxiety and depression among medical students. Rev Bras Educ Med. 2015;39(3):388-94 [access in 4 dez 2019]. Available from: http://www.scielo.br/scielo.php?script=sci_arttext\&pid=S0100$55022015000300388 \& \operatorname{lng}=$ en\&nrm $=$ iso.

6. Baldassin S, Alves TC, de Andrade AG, Nogueira Martins LA. The characteristics of depressive symptoms in medical students during medical education and training: a cross-sectional study. BMC Med Educ. 2008;8:60 [access in $4 \mathrm{dez}$ 2019]. Available from: https://www. ncbi.nlm.nih.gov/pmc/articles/PMC2621219/.

7. Pereira GA, Capanema HXM, Silva MMQ, Garcia IL, Petroianu A. Prevalência de síndromes funcionais em estudantes e residentes de Medicina. Rev Bras Educ Med. 2015;39(3):395-400 [access in 4 dez 2019]. Available from: http://www.scielo.br/pdf/rbem/v39n3/19815271-rbem-39-3-0395.pdf.

8. Vasconcelos TC, Dias BR, Andrade LR, Melo GF, Barbosa L, Souza E. Prevalência de sintomas de ansiedade e depressão em estudantes de Medicina. Rev Bras Educ Med. 2015;39(1):135-42 [access in 4 dez 2019]. Available from: http://www.scielo.br/scielo.php?script=sci_ arttext\&pid=S0100-55022015000100135\&lng=en\&nrm=iso.

9. Olmo NRS, Ferreira LF, Prado AD, Martins LC, Dedivitis RA. Percepção dos estudantes de Medicina do primeiro e sexto anos quanto à qualidade de vida. Diagn Tratamento. 2012;17(4):157-61.

10. Development of the World Health Organization Whoqol-Bref quality of life assessment. The Whoqol Group. Psychol Med. 1998;28(3):551-8.

11. Ramos-Dias JCR, Libardi MC, Zilo CM, Igarashi MH, Senger MH. Qualidade de vida em cem alunos do curso de Medicina de Sorocaba - PUC/SP. Rev Bras Educ Med. 2010;34(1):116-23 [access in 4 dez 2019]. Available from: http://www.scielo.br/scielo.php?script=sci_
arttext\&pid=S0100-55022010000100014\&lng=en\&nrm=iso.

12. Carlotto MS, Câmara SG. Características psicométricas do Maslach Burnout Inventory - Student Survey (MBI-SS) em estudantes universitários brasileiros. PsicoUSF. 2006;11(2):167-73 [access in $4 \mathrm{dez}$ 2019]. Available from: http://pepsic.bvsalud.org/scielo.php?script=sci_ arttext\&pid=S1413-82712006000200005\&lng=pt\&tlng=pt.

13. Maroco J, Tecedeiro M. Inventário de burnout de Maslach para estudantes portugueses. Psic Saúde \& Doenças. 2009;10(2):227-35 [access in 4 dez 2019]. Available from: http://www.scielo.mec.pt/scielo. php?script=sci_arttext\&pid=S1645-00862009000200007\&lng=pt.

14. Fleck MP, Leal OF, Louzada S, Xavier M, Chachamovich E, Vieira G, et al. Desenvolvimento da versão em português do instrumento de avaliação de qualidade de vida da OMS (Whoqol-100). Rev Bras Psiquiatr. 1999;21(1):19-28. doi: 10.1590/S1516-44461999000100006.

15. Fleck MP, Louzada S, Xavier M, Chachamovich E, Vieira G, Santos L, et al. Aplicação da versão em português do Instrumento Abreviado de Avaliação da Qualidade de Vida "Whoqol-bref". Rev Saúde Pública. 2000;34(2):178-83 [access in $4 \mathrm{dez} 2019$ ]. Available from: http://www.scielo.br/scielo.php?script=sci_arttext\&pid=S0034$89102000000200012 \& \operatorname{lng}=$ en\&nrm $=$ iso.

16. Amor EM, Baños JE, Sentí M. Prevalencia del síndrome de burnout entre los estudiantes de medicina y su relación con variables demográficas, personales y académicas. Rev Fund Educ Méd. 2020;23(1):25-33 [access in 26 jul 2020]. Available from: http://scielo.isciii.es/scielo.php?script=sci_arttext\&pid=S201498322020000100005\&lng=es.

17. Tamayo MR. Relação entre a síndrome de burnout e os valores organizacionais no pessoal de enfermagem de dois hospitais públicos [dissertação]. Brasília: Universidade de Brasília; 1997.

18. Pagnin D, de Queiroz V. Influence of burnout and sleep difficulties on the quality of life among medical students. SpringerPlus. 2015;4:676. doi: 10.1186/s40064-015-1477-6.

19. Amorim BB, Moraes L, Sá ICG, Gomes Silva BB, Camara Filho JW. Saúde mental do estudante de medicina: psicopatologia, estresse, sono e qualidade de vida. Rev Psic Divers e Saúde. 2018;7(2):245-54 [access in $4 \mathrm{dez}$ 2019]. Available from: https://www5.bahiana.edu.br/ index.php/psicologia/article/view/1911/1829.

20. Gómez HP, Pérez VC, Parra PP, Ortiz ML, Matus BO, McColl CP, et al. Relación entre el bienestar y el rendimiento académico en alumnos de primer año de medicina. Rev Méd Chile. 2015; 143(7):930-7. doi: 10.4067/S0034-98872015000700015.

21. Mori MO, Valente TCO, Nascimento LFC. Síndrome de burnout e rendimento acadêmico em estudantes da primeira à quarta série de um curso de graduação em Medicina. Rev Bras Educ Med. 2012;36(4):536-40 [access in $4 \mathrm{dez}$ 2019]. Available from: http://www.scielo.br/scielo.php?script=sci_arttext \&pid=S0100 $55022012000600013 \& \operatorname{lng}=$ en\&nrm $=$ iso.

22. Solis AC, Lotufo-Neto F. Predictors of quality of life in Brazilian medical students: a systematic review and meta-analysis. Braz J Psychiatry. 2019;41(6):556-567. doi: 10.1590/1516-4446-2018-0116.

23. Burger PHM, Scholz M. Gender as an underestimated factor in mental health of medical students. Ann Anat. 2018;218:1-6. doi: 10.1016/j.aanat.2018.02.005.

24. Jena AB, Khullar D, Ho O, Olenski AR, Blumenthal DM. Sex

7 REVISTA BRASILEIRA DE EDUCAÇ̄̃o MÉDICA

7 44 (4) : e125; 2020 
differences in academic rank in US medical schools in 2014. JAMA. 2015;314(11):1149-58. doi: 10.1001/jama.2015.10680.

25. Choo EK, van Dis J, Kass D. Time's up for medicine? Only time will tell. N Engl J Med. 2018;379(17):1592-3. doi: 10.1056/ NEJMp1809351.

26. Chazan AC, Campos MR, Portugal FB. Qualidade de vida de estudantes de Medicina da Uerj por meio do Whoqol-Bref: uma abordagem multivariada. Ciênc Saúde Colet. 2015;20(2):547-56. doi: 10.1590/1413-81232015202.05182014.

27. Cavalcante M, Cazolari P, Galliano S, Cohrs F, Sañudo A, Schveitzer M. Qualidade de vida dos estudantes do primeiro e sexto ano do curso de Medicina. Rev Med (São Paulo). 2019;98(2):99-107. doi: 10.11606/issn.1679-9836.v98i2p99-107.

28. Figueiredo AM, Ribeiro GM, Reggiani ALM, Pinheiro BA, Leopoldo GO, Duarte JAH, et al. Percepções dos estudantes de Medicina da Ufop sobre sua qualidade de vida. Rev Bras Educ Med. 2014;38(4):435-43 [access in $4 \mathrm{dez}$ 2019]. Available from: https://www.scielo.br/scielo. php?script=sci_arttext\&pid=S0100-55022014000400004\&lng=en\&n $\mathrm{rm}=\mathrm{iso}$.

29. Gan GG, Hue YL. Anxiety, depression and quality of life of medical students in Malaysia. Med J Malaysia. 2019;74(1):57-61.

30. Cecil J, McHale C, Hart J, Laidlaw A. Behaviour and burnout in medical students. Med Educ Online. 2014;19:25209. doi: 10.3402/ meo.v19.25209.

31. Maia DAC, Maciel RH, Vasconcelos JA, Vasconcelos LA, Filho JOV. Burnout syndrome in medical students: relations with Physical activity. Cade ESP [on line]. 2012;6(2):50-9 [access in $4 \mathrm{dez} 2019$ ]. Available from: https:/cadernos.esp.ce.gov.br/index.php/cadernos/ article/view/57/62.

32. Ortega ME, Ortiz GR, Martínez AJ. Burnout en estudiantes de pregrado de medicina y su relación con variables de personalidad. Ter Psicol. 2014;32(3):235-42. doi: 10.4067/S0718-48082014000300006.

33. Colby L, Mareka M, Pillay S, Sallie F, van Staden C, du Plessis ED, et al. The association between the levels of burnout and quality of life among fourth-year medical students at the University of the Free
State. S Afr J Psychiatr. 2018;24:1101. doi: 10.4102/sajpsychiatry. v24i0.1101.

34. Barker R, Cornwell J, Gishen F. Introducing compassion into the education of health care professionals; can Schwartz Rounds help? J Compassionate Health Care. 2016;3(3) [access in 4 abr 2019]. Available from: https://discovery.ucl.ac.uk/id/eprint/10060031/.

35. Aherne D, Farrant K, Hickey L, McGrath L, McGrath D. Mindfulness based stress reduction for medical students: optimising student satisfaction and engagement. BMC Med Educ. 2016;16 (209) [access in 4 abr 2019]. Available from: https://bmcmededuc.biomedcentral. com/articles/10.1186/s12909-016-0728-8.

\section{AUTHORS 'CONTRIBUTION}

Priscila Gadelha Cazolari contributed with the study concept, data curation, formal analysis, research, funding acquisition and manuscript writing. Matheus de Sousa Cavalcante contributed with data curation, formal analysis, research and manuscript writing. Marcelo Marcos Piva Demarzo contributed with the study concept, data curation, formal analysis, methodology, supervision and manuscript writing. Frederico Molina Cohrs contributed with data curation, formal analysis, methodology, software, validation and manuscript writing. Adriana Sanudo contributed with data curation, formal analysis, methodology, software, validation and manuscript writing. Mariana Cabral Schveitzer contributed with the study concept, data curation, formal analysis, research, methodology and manuscript writing.

\section{CONFLICTS OF INTEREST}

The authors declare no conflicts of interest.

\section{ADDRESS FOR CORRESPONDENCE}

Mariana Cabral Schveitzer. Rua Botucatu, 740, $4^{\circ}$ andar, Vila Clementino, São Paulo, SP, Brasil. CEP: 04023-900.

E-mail: mariana.cabral@unifesp.br 